\title{
A decade of whale watching in an important tourist destination in the Pacific coast of Colombia: Challenges for proper management
}

\author{
Isabel Cristina Avila ${ }^{1, *}$, Luis Fernando Ortega ${ }^{2}$, Cristina Pretel ${ }^{2}$ and Gustavo Mayor ${ }^{2}$ \\ ${ }^{1}$ Grupo de Ecología Animal, Departamento de Biología, Facultad de Ciencias, Universidad del Valle, \\ Ciudad Universitaria Meléndez, Apartado Aéreo 25360, Cali, Colombia \\ ${ }^{2}$ Parques Nacionales Naturales de Colombia, Dirección Territorial Pacífico, Calle 29 Norte No. 6N-4, Cali, Colombia \\ *Corresponding author:isabel_c_avila@yahoo.com
}

\begin{abstract}
Uramba Bahía Málaga Natural National Park is one of the most important places visited by tourists to see humpback whales (Megaptera novaeangliae) in Colombia. Humpback whales arrive from Southern Chile and the Antarctic Peninsula every year between May and December to reproduce, give birth and rear calves. To evaluate the current state of whale watching in Málaga we analyzed tourist visitation data from 2011 to 2019 during the peak whale-watching season (July-October), and during one week in October 2020. We found that whale-watching activity has increased considerably. In 2019, 21,186 tourists realized whale watching in Málaga. Whale watchers per month increased by $108 \%$ and monthly whale-watching boat trips increased by $140 \%$, in the last decade. Currently there are in average 19 boat trips per day $( \pm 18.0)$, and most boats are small $(\leq 15 \mathrm{~m})$. Tourists came mainly from Colombia (90\%). August was the most important month for whale watching. Although environmental education activities are undertaken, currently responsible whalewatching guidelines are overlooked. At present, whale-watching activity produces important economic benefits for local people and neighboring sites, with a monthly expenditure of at least $\$ 362,409$ USD, but to ensure the sustainable continuity of this activity, negative impacts on whales need to be minimized. We classified management challenges into social, economic
\end{abstract}

Keywords: humpback whale, Megaptera novaeangliae, tourism, conservation, Marine Protect Area, South America

\section{ARTICLE INFO \\ Manuscript type: Article \\ Article History \\ Received: 14 December 2020 \\ Received in revised form: 15 June 2021 \\ Accepted: 16 June 2021 \\ Available online: 15 September 2021}

Responsible Editor: Eduardo Morteo

\section{Citation:}

Avila, I.C., Ortega, L.F., Pretel, C. and Mayor, G. (2021) A decade of whale watching in an important tourist destination in the Pacific coast of Colombia: Challenges for proper management. Latin American Journal of Aquatic Mammals 16(1): 23-32.

https://doi.org/10.5597/lajam00267 and biological aspects. From a social perspective, operators should form a whale-watching community association; this would improve cooperation amongst operators, promote good practices in whale-watching and reduce pressure on whales. Economic recommendations include 1) whale-watching trips handled mainly by local people; 2 ) ticket prices unification; and 3) investment in tourist facilities. Biological recommendations focus on the welfare of whales and include: 1) follow the current whalewatching recommendations strictly; 2 ) reduce transit speeds to below 10 knots in the area during whale season; 3) use propeller guards; 4) promote land-based whale watching; 5) implement acoustic whale tourism; 6) reinforce environmental education programs; and 7) support long-term monitoring and scientific research. Based on these three aspects, we urge environmental and ethnic authorities, conferring with relevant stakeholders, to determine the whale-watching carrying capacity of the area and to promote a responsible tourism. Authorities need to strengthen the monitoring, oversight and control of this growing tourist activity in order to ensure its long-term persistence.

\section{Introduction}

Whale watching is a growing tourism activity worldwide. Commercial whale watching began in South America in the 1990s (Hoyt and Iñíguez, 2008; Hoyt and Parsons, 2014). In Colombia, whale watching started in Bahía Málaga (Valle del Cauca Department) in 1994 (Arias-Gaviria et al., 2011). Since August 2010, this area is part of the Uramba Bahía Málaga Natural National Park (Málaga NNP) (Avila et al., 2015). Whalewatching activities then spread to Tribugá and Cupica gulfs (Chocó Department) in 1997, and Tumaco (Nariño Department) around 2010 (Arias-Gaviria et al., 2011). Whale-watching tourism generates income and employment in coastal communities and raises awareness on whale and dolphin conservation needs (Zeppel and Muloin, 2008). In 2008, more than 13 million people took part in whale watching tours in 119 countries worldwide, generating an estimated total expenditure of $\$ 2.1$ billion USD (O'Connor et al., 2009). For the same year, in Bahía Málaga 6,663 whale watchers and 267 boat trips were recorded, generating $\$ 99,954$ USD in direct expenses (only ticket expenses) (Avila et al., 2015). However, this activity can generate disturbance resulting in changes in behavior, collisions with boats, and pollution, which may have an impact on the whales' reproductive 
success, habitat choice and survival (Parsons, 2012; Avila et al., 2015). In fact, in Málaga NNP and other breeding areas, humpback whales changed their behavior with the beginning of boat-based whale-watching activity (e.g. Scheidat et al., 2004; Morete et al., 2007; Avila et al., 2015; Fiori et al., 2019; Amrein et al., 2020). Humpback whales engage in complex acoustic behaviors producing social sounds and songs, some of which are associated with reproduction (Payne and McVay, 1971; Oña et al., 2019). Therefore, boat noise could disturb and mask these vocalizations (Southall, 2005; Dunlop et al., 2010). Negative impacts caused by whale watching are likely a consequence of the combination of the presence of boats and the underwater noise they produce (Lusseau and Bejder, 2007; Weilgart, 2007; Wright et al., 2007). Currently, whale watching using boats is one of the main threats to marine mammals worldwide and is affecting 58 marine mammal species - almost $50 \%$ of all marine mammals - in 82 countries (Avila et al., 2018).

The humpback whale, Megaptera novaeangliae, is the main target of most whale watching operations worldwide (55\% of countries performing whale watching) (O'Connor et al., 2009). Humpbacks arrive annually into Colombian waters from May to December from Southern Chile and the Antarctic Peninsula to reproduce, give birth and rear their calves (Avila et al., 2020). Málaga NNP is one of the most important breeding sites for this species in the Southeast Pacific, with more than $70 \%$ of observed groups containing calves (Avila, 2006; Flórez-González et al., 2007). Málaga's economy is based primarily on fishing, tourism, timber extraction and subsistence farming ${ }^{1}$ (Escobar, 2017). One of the most important tourist attractions in the area is the presence of humpback whales, making Málaga NNP the main whale watching destination in Colombia (Hoyt and Iñíguez, 2008; Arias-Gaviria et al., 2011). However, due to fishing, whale-watching activities, and its proximity to the major Buenaventura Port, Málaga NNP has an intense boat traffic, which overlaps spatially and temporally with areas used by humpback whales (Avila et al., 2017). Since whales are known to be affected by whalewatching boats, a series of recommendations and rules have been generated for the proper observation of whales worldwide (IWC, 2020). Colombia has established some (non-enforceable) recommendations since 2001 to minimize negative impacts on whales by whale-watching in the Colombian Pacific (Avila et al., 2015; MADS, 2017). These recommendations stipulate that: 1) boats must not approach the whales closer than 200 meters; 2 ) boats must approach whales slowly ( $\leq 5$ knots), in parallel and slightly from behind; 3 ) boats can stay for a maximum of 30 minutes with a group of whales; 4) a maximum of three boats can stay simultaneously with a group of whales; 5 ) boats should avoid following animals with calves; and, 6) swimming with whales is not allowed (MADS, 2017). Furthermore, because of the collision risk and other potential disturbance from boat traffic in the whales' area, boat speed should not exceed 10 knots and propeller guards should be used (Avila et al., 2017). In addition, operators who want to run whale-watching boat trips in Málaga NNP have to be certificated annually by the environmental authorities and have to depart from Juanchaco dock (Fig. 1), where they receive specific instructions by the environmental authorities. Although the recommendations control whale-watching activities at Málaga NNP, there has been great concern in recent years about the increase in number of boats and whale watchers in the area. Besides, knowledge on whale-watching tourism in Colombia is scarce, as there are currently only a few studies (e.g. Avila et al., 2015; Zapetis et al., 2017; Soto-Cortés et al., 2021). Therefore, the purpose of this research was to evaluate the current state of whale watching in Málaga NNP, how it has changed in time, evaluate the levels of compliance with whale-watching recommendations and identify challenges for the conservation of whales.

\section{Materials and Methods}

Research was conducted during nine breeding seasons, from 2011 to 2019 during the whale-tourism season in Málaga between July and October. In addition, although Málaga NNP was closed for tourism in 2020 because of the Covid-19 pandemic, we made observations from 2-6 October. Uramba Bahía Málaga Natural National Park is located at the Bay of Málaga in the Pacific coast of Colombia between $03^{\circ} 51^{\prime} \mathrm{N}$ and $03^{\circ} 57^{\prime} \mathrm{N}$, and $77^{\circ} 19^{\prime} \mathrm{W}$ and $77^{\circ} 25^{\prime} \mathrm{W}, 36 \mathrm{~km}$ north of Buenaventura city, the main commercial port in the Colombian Pacific, and near the Naval Base Bahía Málaga (Naval Base) (Fig. 1). This region is characterized by high rainfall ( $6000 \mathrm{~mm}$ per year) and warm surface waters (25 to $27^{\circ} \mathrm{C}$ ) and relative humidity around $90 \%$ (Rangel, 2004). The average water depth in the study area is $30 \mathrm{~m}$. Málaga NNP is $100 \%$ marine and covers an area of $471 \mathrm{~km}^{2}$. Málaga NNP is characterized by a great diversity of flora, fauna and a variety of habitats such as rivers, marine bottoms (sand and mud bottoms, and rocky reefs), beaches, islands, rocky cliff areas, and an estuary bordered by mangrove forests ${ }^{1}$. The region has six settlements: Juanchaco, Ladrilleros, La Barra, La Plata-Bahía Málaga, Chucheros-El Tigre and Puerto España-Miramar, with a population of 4000 , mainly afro-descendants, and to a lesser extent by indigenous and mestizo people ${ }^{2}$ (Escobar, 2017). To get to Málaga NNP, people take a 45-minute boat ride from the port of Buenaventura to Juanchaco, which is the largest village in the area and whale-watching trips set off from its dock.

Operators and tourists who participate in whale-watching boat trips in Málaga NNP have to arrive to Juanchaco village (Fig.1) to attend a talk offered by the Park staff, who provide information about whales, whale watching and conservation actions. In Juanchaco dock, before each whale-watching boat trip, the operator takes a local guide or "interpreter" onboard and receives a whale-watching flag from the environment authority that they are obliged to place in a clearly visible location on the boat. Only boats with flags are permitted to do whale watching in the Park. Boat operators who want to take whale watchers have to get a certification by attending an annual workshop led by Park rangers, with the collaboration of other organizations (Regional Autonomous Corporation of the Valle del Cauca - CVC, maritime authority - DIMAR, Community Councils of Black Communities and NGOs) to educate them about whale biology, ecology and behavior, as well as best practices for whale watching. Only certified operators receive the whale-watching flag from the Park's office. Also, interpreters have to be trained and certified annually

\footnotetext{
1. INVEMAR, UNIVALLE and INCIVA (2006) BIOMÁLAGA: Valoración de la biodiversidad marina y costera de Bahía Málaga (Valle del Cauca), como uno de los instrumentos necesarios para que sea considerada un área protegida. Final Report. Cali, Colombia. $813 \mathrm{pp}$.

2. MAVDT- Ministerio de Ambiente, Vivienda y Desarrollo Territorial (2010) Resolución Número 1501 “Por medio de la cual se declara, reserva, delimita y alindera el Parque Nacional Natural Uramba Bahía Málaga". Ministerio de Ambiente, Vivienda y Desarrollo Territorial, Bogotá, Colombia. 17 pp.
} 


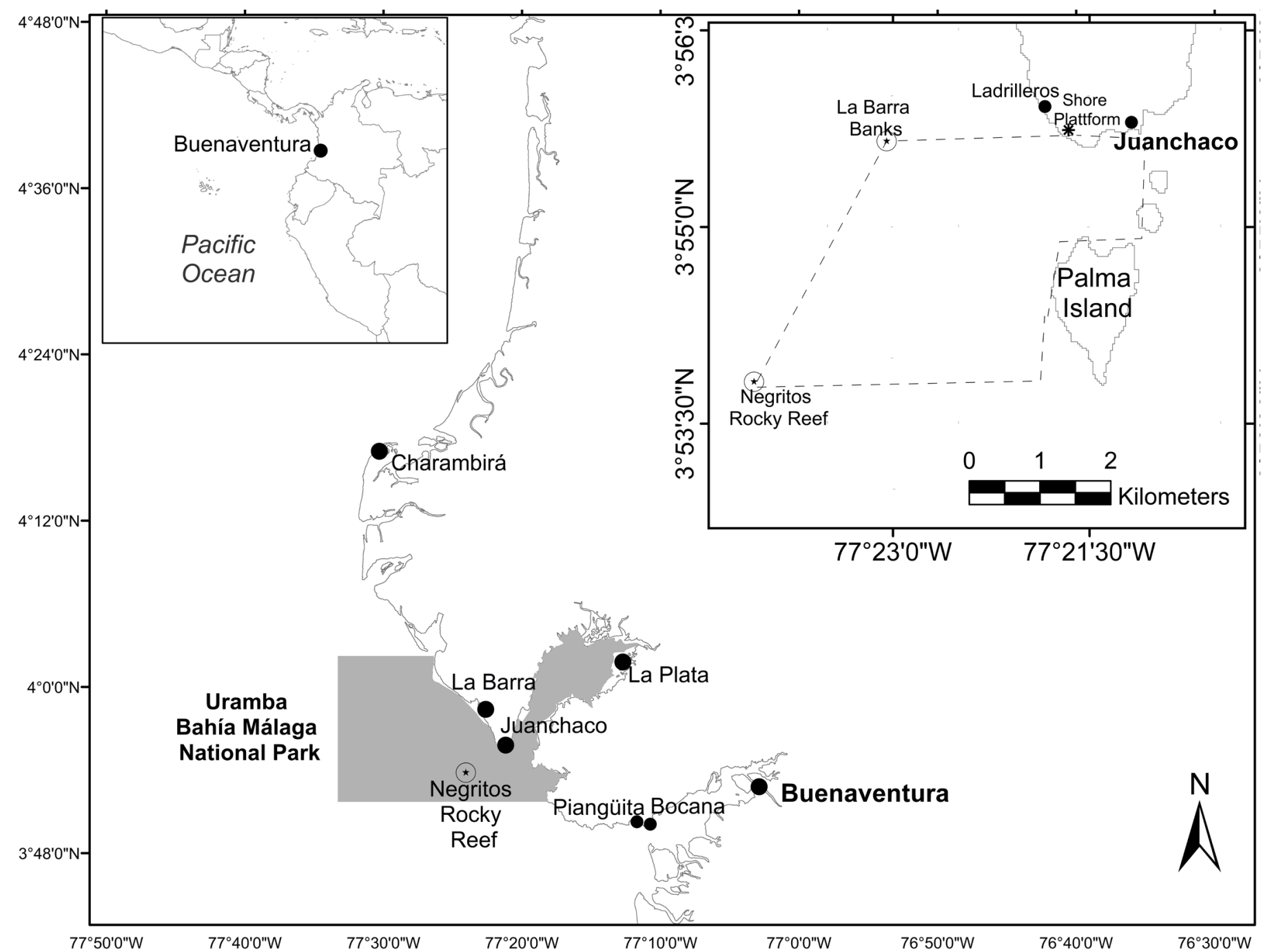

Figure 1. Study site in Uramba Bahía Málaga Natural National Park, in the Colombian Pacific, South America. The area of the Natural National Park is denoted in the shaded area. Observations were made from a shore platform between the towns of Juanchaco and Ladrilleros at a height of $20 \mathrm{~m}$ above the mean lowest tide water level. The area of observation is shown within the dotted lines.

by the Park. The staff at Uramba Bahía Málaga Natural National Park have several assignments during whale-watching seasons (Fig. 2). We obtained total number of boat trips, information about the origin of boat operators and whale watchers from the Uramba Bahía Málaga Natural National Park's official records. Information about name, age and origin of tourist participants is registered in the Park's official records.

To evaluate compliance of whale-watching boats with the recommendations, two Park staff members trained in whale watching made observations from a 20-meter-high land-based platform using $7 \times 50$ binoculars. The effective area of observation was $14 \mathrm{~km}^{2}$. The observation area was delimited by the Negritos rocky reef, La Barra sand banks and Palma Island (Fig. 1). The observations were conducted between 8:00h and 17:00h when conditions were optimal: no rainfall, good visibility $(6 \mathrm{~km})$ and Beaufort wind strength/speed less than four. From the land-based platform, groups of whales and tourist boats were monitored. Whales were detected by blows or aerial behavior. For each encounter, observers recorded the approximate location of whales and boats (using the azimuth position), the time that each boat spent with a group of whales and the speed of the boats when approaching the groups of whales. Boat speed was roughly estimated in relation to the speed of whales as 'fast' (more than $200 \mathrm{~m} / \mathrm{min}$ or $>5$ knots approx.), or 'slow' (less than
$200 \mathrm{~m} / \mathrm{min}$ or $\leq 5$ knots approx.). In addition, number of boats following whales was counted.

To estimate the expenditures of whale-watching tourists in the Málaga NNP area, costs were obtained using the number of tourists per month, and then calculating the annual cost of transport, whale-watching trips, average accommodation, and average food costs. As this was a rough estimation based on the average costs of transport, food and accommodation in the area each year, we assumed that all the persons expended similar amount of money for going whale watching. The Colombian peso (COP\$) is the unit of currency in Colombia, and we converted costs to US dollars, where $\$ 1$ USD is equivalent to $\$ 3,281$ COP (average value for 2019; DW, 2020). The direct expenses generated by whale watching in the area were estimated based on the number of whale watchers and the cost of a whale-watching tour. Total expenses in the region included transport from Buenaventura to Juanchaco (round trip), food and accommodation for a weekend (two days, one night). We also estimated the number of direct jobs generated by whale-watching activities in Málaga NNP, which was estimated from the number of whale-watching boats, hotels and restaurants in the area. 
Table 1. Characterization of whale-watching activity in Uramba Bahía Málaga National Natural Park from 2011 to 2019 (July to October). ND = no data available. Local boats $=$ refers to boats from Málaga NNP area.

\begin{tabular}{|c|c|c|c|c|c|c|c|c|c|}
\hline Whale-watching activity & 2011 & 2012 & 2013 & 2014 & 2015 & 2016 & 2017 & 2018 & 2019 \\
\hline Number of total whale watchers & 10,197 & 11,071 & 11,035 & 10,995 & 11,957 & 15,929 & 16,255 & 23,122 & 21,186 \\
\hline Average whale watchers per month & $2,549 \pm 1,868$ & $2,768 \pm 1,790$ & $2,759 \pm 1,452$ & $2,749 \pm 2,010$ & $2,989 \pm 2,100$ & $3,982 \pm 2,589$ & $4,064 \pm 2,853$ & $5,781 \pm 2,729$ & $5,297 \pm 3,482$ \\
\hline Total number of boat trips & 701 & 855 & 791 & 848 & 932 & 1,123 & 1,277 & 1,792 & 1,678 \\
\hline Average boat trips per month & $175 \pm 119$ & $214 \pm 128$ & $198 \pm 104$ & $212 \pm 138$ & $233 \pm 167$ & $281 \pm 159$ & $319 \pm 196$ & $448 \pm 195$ & $420 \pm 252$ \\
\hline Average boat trips per day & ND & ND & $8.9 \pm 7.1$ & ND & $10.4 \pm 8.5$ & $12.5 \pm 11.8$ & $14.2 \pm 13.4$ & $16.5 \pm 17.2$ & $18.6 \pm 18.0$ \\
\hline $\begin{array}{l}\text { Maximum number of boat trips } \\
\text { per day }\end{array}$ & ND & ND & 76 & ND & 93 & 115 & 108 & 139 & 118 \\
\hline Percent of the trips on weekends & ND & ND & ND & ND & 75 & ND & 75 & 70 & 62 \\
\hline Number of different boats & ND & ND & ND & ND & ND & ND & 64 & 154 & 173 \\
\hline $\begin{array}{l}\text { Percent of small boats used in the } \\
\text { trips (of the total boat trips) }\end{array}$ & ND & ND & ND & ND & ND & ND & 98 & 99 & 98 \\
\hline $\begin{array}{l}\text { Percent of local boats used in the } \\
\text { whale-watching trips (of the total } \\
\text { boat trips) }\end{array}$ & ND & ND & ND & ND & 44.8 & ND & 38.5 & 45.1 & 54.4 \\
\hline $\begin{array}{l}\text { Month with most whale-watching } \\
\text { activity }\end{array}$ & Aug. & Aug. & Aug & Aug. & Aug. & Aug. & Aug. & Aug. & Aug. \\
\hline Number of certified interpreters & ND & 18 & 20 & 25 & 21 & 17 & 27 & 30 & 16 \\
\hline Number of certified operators & ND & ND & ND & ND & ND & ND & 44 & 54 & 53 \\
\hline Direct expenses (USD thousands) & 77.7 & 84.4 & 84.1 & 83.8 & 91.1 & 121.4 & 123.9 & 176.2 & 161.4 \\
\hline $\begin{array}{l}\text { Average monthly direct expenses } \\
\text { (USDS thousands) }\end{array}$ & $19.4 \pm 14.2$ & $21.1 \pm 13.6$ & $21.0 \pm 11.1$ & $20.9 \pm 15.3$ & $22.8 \pm 16.0$ & $30.3 \pm 19.7$ & $31.0 \pm 21.7$ & $44.0 \pm 20.8$ & $40.4 \pm 26.5$ \\
\hline Total expenses (USD thousands) & 419.6 & 539.9 & 544.9 & 536.2 & 590.4 & 805.9 & 847.2 & 1497.5 & 1449.6 \\
\hline $\begin{array}{l}\text { Average monthly total expenses } \\
\text { (USD thousands) }\end{array}$ & $104.9 \pm 76.9$ & $135.0 \pm 87.3$ & $136.2 \pm 71.7$ & $134.0 \pm 98.0$ & $147.6 \pm 103.7$ & $201.5 \pm 131.0$ & $211.8 \pm 148.7$ & $374.4 \pm 176.7$ & $362.4 \pm 238.3$ \\
\hline
\end{tabular}

(A)
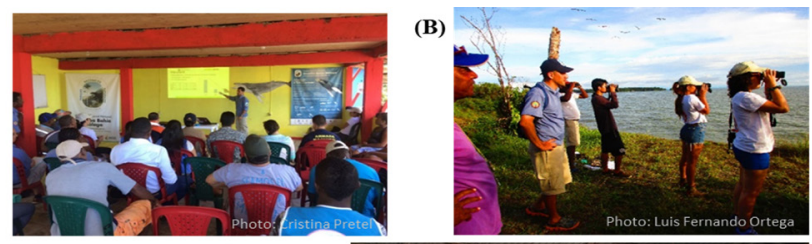

(C)

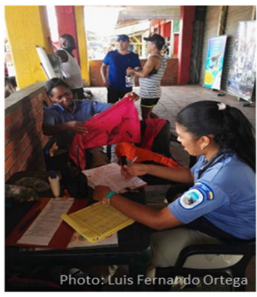

(E)

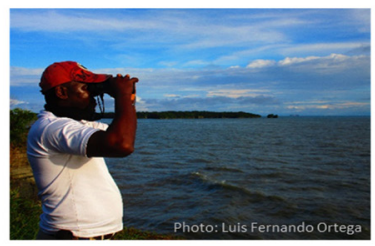

(F)

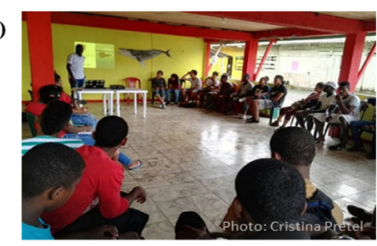

Figure 2. Uramba Bahía Málaga Natural National Park' staff assignments during whale-watching seasons; (A) Workshop with boat operators about whales and whale-watching good practices; (B) Training volunteers (Volunteer Ranger Program) in watching whales and boats from the shore platform; (C) Boat operators' control before the whale-watching tour and filling of the Park's official records; (D) Pre-whale-watching tour talks to tourists; (E) Observation of whales and boats from the shore platform; and (F) Training environmental interpreters (guides) in biology of whales and conservation actions.

\section{Results}

Data on whale-watching activity at Uramba Bahía Málaga Natural National Park was obtained from the Park's official records for a 9-year period (2011-2019) from July to October with a total of 36 months (Table 1). Due to the abnormal situation of season
2020 and lack of enough data, this season was not included in the data analysis (a description on what we found in October 2020 is made at the end of this section). During 2011-2019, number of whale watchers and boat trips in the area increased considerably, from 10,197 tourists in 2011 to 21,186 in 2019. Number of boat trips also increased, from 701 in 2011 to 1,678 in 2019 (Table 1). Number of whale watchers per month increased by $108 \%$ in the last nine years, from $2,549( \pm 1,868)$ in 2011 to $5,297( \pm 3,482)$ in 2019 (Fig. 3A). Additionally, monthly numbers of whale-watching boat trips increased by $140 \%$ in the area, from $175( \pm 119)$ in 2011 to $420( \pm 252)$ in 2019 (Fig. 3B). Currently there are in average 19 boat trips per day $( \pm 18.0)$. However, the number of boat trips per day increased, from a maximum of 76 in 2013 to 118 in 2019 (Table 1). The number of different boats conducting whale-watching activities increased from 64 in 2017 to 173 in 2019 (Table 1, Fig. 3A-B). The season with most whale watching activity in the last decade was 2018 , with 23,122 visitors and 1792 whale-watching boat trips.

The majority ( $\geq 98 \%$ ) of boats used for whale watching were small ( $\leq 15 \mathrm{~m}$ length; Fig. 4 ), and the rest were medium sized ( $60 \mathrm{~m}$ length). Most of the boats were from people of Buenaventura area, e.g. Buenaventura, Piangüita, La Bocana (>54.8\%), except for 2019 , when there were mainly local boats from the Bahía Málaga area (54.4\%), i.e. Juanchaco, Ladrilleros, La Barra, La Plata (Table 1). Local whale-watching boats were small ( $\sim 7 \mathrm{~m}$ length), with a passenger capacity of 10-20 people, typically powered by two $40 \mathrm{hp}$ outboard engines, while Buenaventura whale-watching boats were larger in size ( $15 \mathrm{~m}$ length), with a passenger capacity of 30-40, and typically powered by two $100 \mathrm{hp}$ outboard engines. A few (three) larger boats were also from Buenaventura ( 60 m length, with a 60-80 passenger capacity and powered by $400 \mathrm{hp}$ engines). During the study period, $64 \%$ of the boats coming from Buenaventura arrived to Juanchaco dock before the whale-watching trip, so 
A

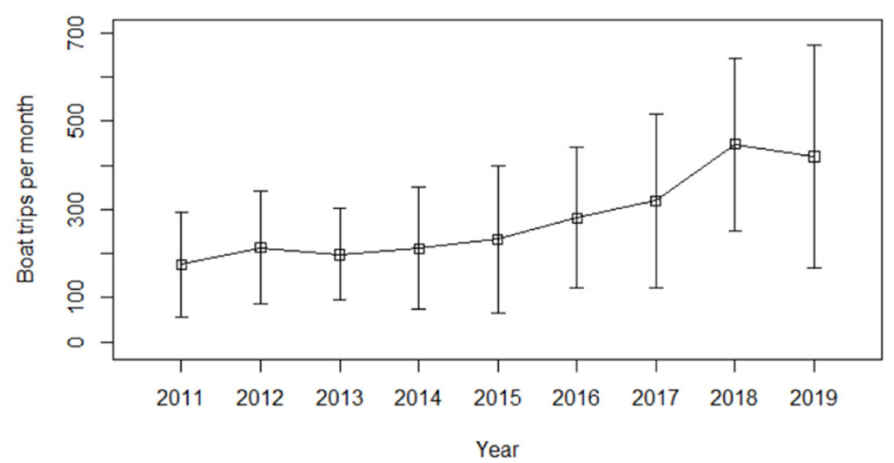

C

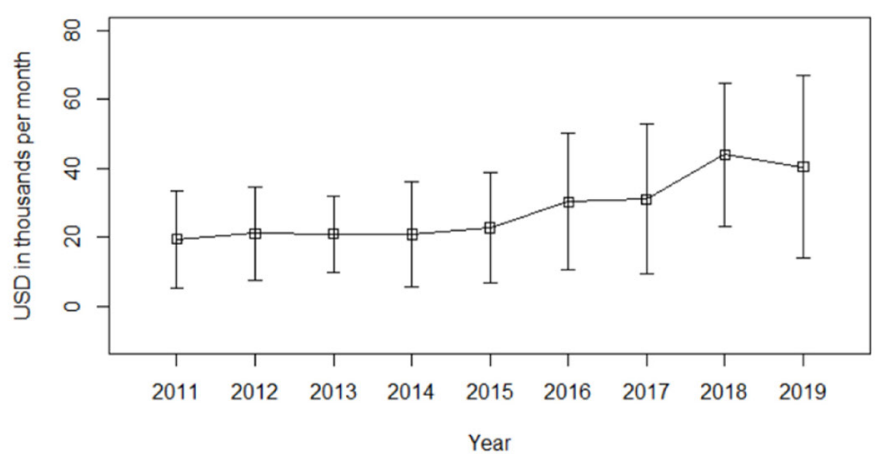

B

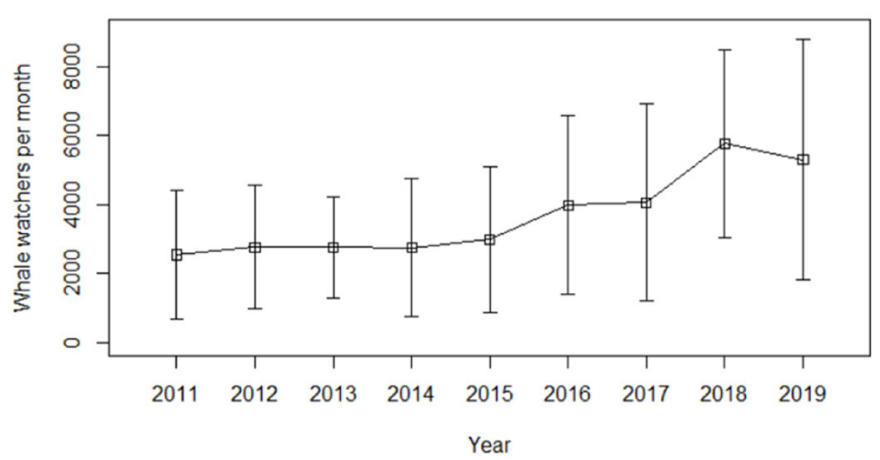

D

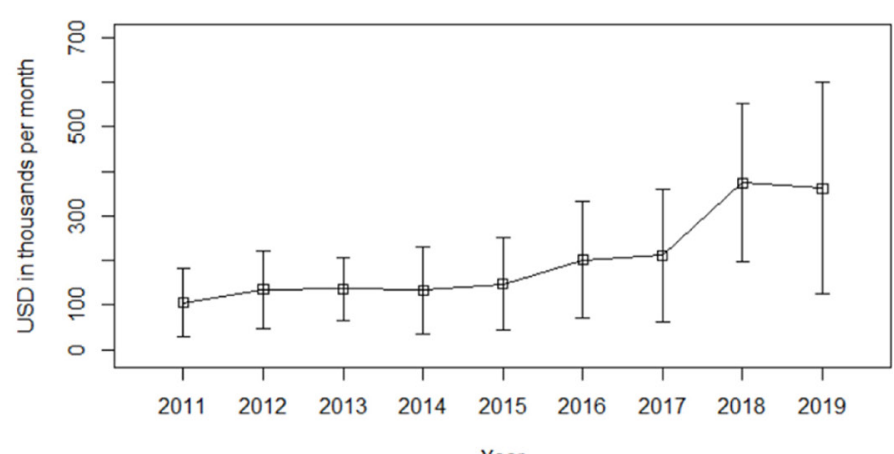

Figure 3. Whale-watching activity in Uramba Bahía Málaga Natural National Park, Colombia, from 2011 to 2019 (July to October); (A) Average number of whale watchers per month; (B) Average number of boat trips per month; (C) Average "direct expenses" generated by whale watching in US dollars per month (i.e. from ticket sales); and (D) Average "total expenses" generated by whale watching in US dollars per month (i.e. from local transport, food and accommodation for two days). Bars show the standard deviation.

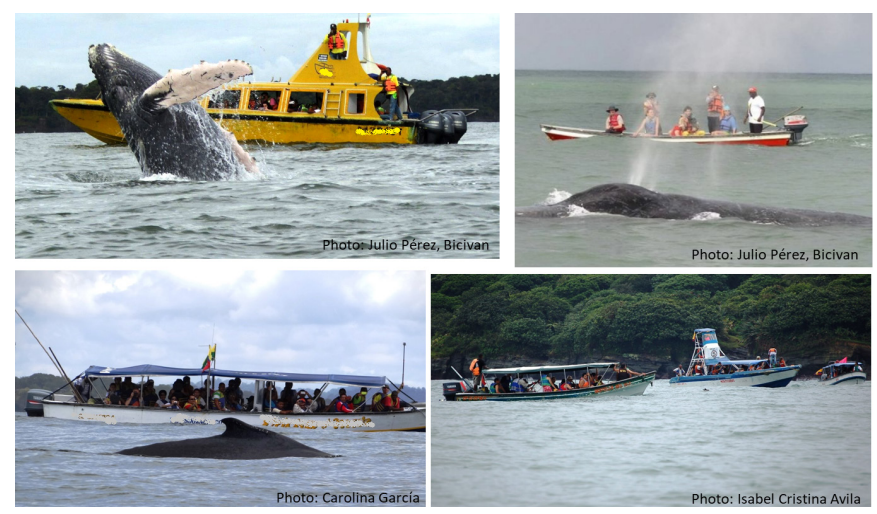

Figure 4. Typical whale-watching boats at Uramba Bahía Málaga Natura National Park, Colombia, between 2011 and 2020.

$36 \%$ of Buenaventura boats run directly to do whale watching without attending the talk offered by environmental authorities, without taking any interpreter and without receiving any flag. On the other hand, although during the study period no collisions were registered/reported between a whale-watching boat and a humpback whale, from 2013 to 2020 five different live humpbacks in Málaga NNP were recorded with scars or injuries consistent with collisions with boats.

Whale watching was more popular during weekends and holidays (more than $60 \%$ of boat trips). August was the most important month for whale watching, which coincides with the greatest density of whales in the area and Colombian school holidays. Whale watchers came mainly from Colombia (90\%), while the rest visited from Argentina, Belgium, Brazil, Chile, Curaçao, Germany, France, Israel, UK, USA and Venezuela. At least 174 local environmental interpreters (an average of 21 per year) and 151 boat operators (50 in average per year) were trained and certified (Table 1).

Whale-watching activities in the Málaga NNP, as of 2019, generated several jobs in the area: 76 people employed in whalewatching boats, 150 people employed in hotels and 70 people employed in restaurants. So, 296 local people have benefited by humpback whales in Málaga NNP. The cost per ticket of a whale-watching tour oscillated around \$8 USD and this cost has changed very little in the last decade. Direct expenses increased from $\$ 77,697$ USD in 2011 to $\$ 161,429$ USD in 2019 (Table 1); average monthly direct expenses increased by $107.8 \%$ in the last nine years, from \$19,424 USD in 2011 to \$40,357 USD in 2019 (Fig. 3C). Total expenses went from \$419,566 USD in 2011 to $\$ 1,449,636$ USD in 2019 (Table 1), and monthly total expenses increased by $245 \%$, from $\$ 104,891$ USD in 2011 to $\$ 362,409$ USD in 2019 (Fig. 3D). As observed with whale watchers and boat trips, expenses were similar between 2011 and 2016, and an increase occurred for 2017 and 2019 (Fig. 3C-D).

In addition, there was a lack of a whale-watching operators' community association. It was noted that whale watching operators prioritized competition amongst themselves, keeping whale-watching tour prices low and expanding participant level to increase revenue. The market for whale watching in the Málaga NNP had two forms of marketing: 1) operators with capacity to invest in advertising and sell tourist packages that include accommodation, food and whale watching, 2) offered directly by local operators to tourists who have not purchased a tour package beforehand. The sale of tourist packages has created conflicts in several cases since, according to the local people, the 
first model leaves very few benefits in the community. Another conflict occurred due to competition in ticket prices, where discounts were being made to attract more tourists. However, this generated loss of service quality, since this competition focuses on economic gain and neglects service quality.

In relation to operator compliance with whale-watching recommendations, we only used data of 2019 , as enough field data were available for this year. In 2019 during 228 hours of observation over the 4-month period of the whale watching season, 144 whale pods were followed by boats, $55 \%$ of them being mother-calf pairs. There was a minimum of two and a maximum of 14 boats simultaneously with group of whales. The majority of boats (76.5\%) approached whales at a "fast" speed ( $\geq 5$ knots). Duration of an individual boat's encounter was $42.8 \mathrm{~min}$ in average ( \pm 6.8$)$. Variables as distance of boats to the whales and behavior of whales were not measured.

Finally, in respect to the season 2020, although Málaga NNP was closed to tourism because of the Covid-19 pandemic, from 2-6 October we observed 10 different boats practicing whale watching in the area. Boats were small ( $\leq 15 \mathrm{~m}$ length), and were mainly from Buenaventura (70\%). On a weekend, we registered nine whale-watching boat trips per day and estimated 150 whale watchers per day. There was a minimum of two and a maximum of five boats simultaneously with a group of whales. Boats followed mainly groups with calves (80\%). During this season no control, surveillance and education activities were carried out by the environmental authorities. In addition, the local community told us about their economic problems due to the lack of whale-watching tourists.

\section{Discussion}

Uramba Bahía Málaga National Park is an important tourist destination for whale watching in Colombia. Whale-watching activity in the area has increased considerably since 2011. Number of whale watchers per month increased by $108 \%$ in the last decade, and the current 5,297 tourists for 2019 represent $32 \%$ of the monthly number of tourists that visit the region of the Valle del Cauca Department ${ }^{3}$. This increase allows us to assume that humpback whales have now become an important tourist attraction in the region, and every year more people are traveling to watch them. This activity has a significant potential for further growth; however, the growth in whale watching has led to management problems and challenges, including social, economic and biological aspects.

\section{Social aspects}

Currently around 300 local people and 21,000 visitors are directly benefited by humpback whales in Málaga NNP. Although visitors are mainly Colombian, whale-watching activity in Málaga has also benefited people from various parts of the world (e.g. the Americas and Europe). In Málaga NNP many authorities converge (i.e. six communities of Málaga, National Parks, DIMAR, CVC), so the main challenge is to achieve an agreement of understanding between these authorities for the administration, planning and responsible management of whale-watching activity, respecting their administrative autonomies, but with the common purpose of conservation and responsible use of whales and other marine life. The regulation of the whale-watching activity should be based on the following precepts: a) the principle of joint responsibility of all parties in the ordering of the activity; b) access to the benefits derived from the activity and the well-being of local communities must be equitable; $c$ ) the need to incorporate an associative model that allows for organizational strengthening, cooperative work, that favors the reduction of pressures and the promotion of good whale-watching practices. A recent published study showed that for 2015, humpback whale-watching activity in Bahía Málaga met only $16 \%$ of the conditions for sustainable governance, and it was characterized by unevenness in connections with markets (i.e. price variability and connections with intermediaries), income inequality, the lack of a whalewatching operators' association, and the lack of support from government organizations (Soto-Cortés et al., 2021). Therefore, we encourage the environmental authorities and local people to facilitate the formation of an association. Forming a whalewatching community association would improve cooperation amongst operators, which should reduce pressure on the whales, promote more equitable benefits for local communities and enhance best whale-watching practices.

\section{Economic aspects}

Whale-watching activity in Málaga NNP produces important economic benefits to local people and neighboring communities (e.g. Buenaventura, Piangüita, La Bocana), and since 2017 these benefits have increased substantially. Our results indicate that humpback whale-watching in Málaga is currently worth an estimated \$1.4 million USD annually as a tourist attraction, an economic input that did not exist in the region two decades ago. As fisheries are declining worldwide (Pauly and Zeller, 2015) and mining and timber extraction are restricted and limited in Málaga (Escobar, 2017), whale watching may serve as a viable economic alternative for people of Uramba Bahía Málaga National Park and neighboring coastal communities. In addition, currently boats used for whale watching are half from Buenaventura (54.4\%), while in 2008 boats were mainly local (70.3\%), i.e. from Málaga NNP area (Avila et al., 2015). So, whale-watching activity in Málaga NNP is now benefiting not only local people but neighboring communities as well. However, we identified conflicts that arise by price competition, where operators are forced to sell very unexpensive tickets to get enough tourists on their boats. Even the costs per ticket for whale watching have changed very little in the last decade, and are well below prices paid in the rest of the world 4 (e.g. Hoyt and Iñiguez, 2008) minimizing economic benefits for local communities. We do not have enough information to calculate if under those circumstances the whale-watching operations are financially viable in the long-term (i.e. are tickets paying for decent wages and boat/motor maintenance and depreciation), but it certainly undermines the potential economic benefits of the activity for local people. Therefore, to resolve such problems it is important to: a) unify ticket prices and establish a roster system to avoid competition that brings social conflicts and loss of service quality; b) make an adjustment in prices in order to be able to

3. Gobernación del Valle del Cauca (2017) Análisis y diagnóstico turismo Valle del Cauca. Gobernación del Valle del Cauca and Alcaldía de Cali, Secretaría de Turismo, Colombia. 104 pp.

4. Castro, C., Kaufman, G. and Hamilton, P. (2015) Whalewatching growth and socioeconomic development of communities in the Machalilla National Park-Ecuador. Paper SC/66a/WW/18 presented to the Scientific Committee, International Whaling Commission, San Diego, USA, May-June 2015. [Available from the Office of the International Whaling Commission, The Red House, 135 Station Road, Impington, Cambridge, Cambridgeshire CB4 9NP, UK, <http://iwcoffice.org/>] 
reinvest in the care and maintenance of boats; c) operators that sell tourist packages should exclude the whale-watching tour leaving it in the hands of local operators, so this resource goes directly to the local community; d) to invest in the adequacy of tourist facilities, e.g. in tourist service room, information and land-based control checkpoints, land-based whale-watching kiosk, and cleaning of the beaches; e) to generate an emergency mitigation fund to address possible economic crises, such as those generated in year 2020 by the Covid-19 pandemic. Finally, the marketing used by tour operators, the national and departmental government for the promotion of the destination, must be articulated with the regulatory actions defined by the Park, since generally visits are encouraged without considering the regulations associated with the system load capacity and compliance with regulations. Best practices reduce impacts on whales, but also ensure the long-term sustainability of this economic activity for local communities.

\section{Biological aspects}

Málaga NNP is an important breeding and calving ground for the Southeast Pacific population of humpback whales (Avila, 2006; Flórez-González et al., 2007). However, we identified that whales are currently at risk because whale-watching recommendations have been often overlooked (in 2019 as happened in 2008; Avila et al., 2015) and because of the increase in numbers of whalewatching boats in the area. We identified that contrary to what is stipulated in Colombian whale-watching recommendations (MADS, 2017), boats followed mother-calf groups more often than other groups, approached at speed higher than recommended, and stayed longer than 30 minutes with whales. Although only three boats are allowed to be around whale groups simultaneously (MADS, 2017), there were times when there were up to 14 in 2019. Previous work in Málaga NNP has shown that not following recommendations for humpback whale watching affected whales' behavior negatively, with whales modifying their behavior by decreasing their breathing rate, moving faster and more erratically, increasing breaching frequency, and decreasing their period of resting behavior (Avila et al., 2015). Therefore, prevention and control and compliance with current recommendations need to be strengthened on land and in water. To advance in this item it is necessary to have an inter-institutional alliance between the environmental authorities (CVC, National Parks), as well as the support of the maritime authority DIMAR, and ethnic authorities (afro-descendant and indigenous communities of Málaga).

Moreover, as Málaga NNP is a breeding site for humpback whales, where more than $70 \%$ of sighted groups are with calves (Avila, 2006; Avila et al., 2015), we acknowledge that it is difficult to avoid following mothers with calves. So, we recommend to revise this statement and evaluate an alternative, e.g. avoid following these kind of groups when a) calves are newborn i.e. three times smaller than the size of the adult, white color on the flanks and ventrally, and with scars and fetal folds on the caudal fin (Ferreira et al., 2011; Faria et al., 2013); b) animals are resting, e.g. floating on the surface, or/and c) display an evasive behavior when the boat approaches.

Currently in Málaga NNP there is more traffic of whale-watching boats than a decade before, as number of boat trips per month increased by $140 \%$ in the last decade. Besides, boat trips per day went from an average of six in 2008 (Avila et al., 2015) to 19 in 2019, and in 2019 a maximum of 118 boat trips per day were recorded in the area. Consequently, the impact of such traffic over the whales and their habitat is of major concern. Our study did not include other boat traffic, like fishing, Navy boats, merchant ships, and local transport; the latter also has increased (from Buenaventura to Málaga) to transport the growing number of tourists. However, previous studies identified that vessel traffic (tourism, transport, fishing and Navy) in this area is relatively high (4.5 vessels per hour; Avila et al., 2017), and that in recent years, the number of fishing boats has increased due to a growing fishing effort (Castellanos-Galindo et al., 2011). An increase in boat traffic during whale season is a major concern, as maritime traffic is one of the greatest global threats to whales, due to the high frequency of boat-whale collisions and noise pollution (Van Waerebeek et al., 2007; Avila et al., 2018; Schoeman et al., 2020). Based on stranding records, between 1986 and 2006 , approximately $1.6 \%$ of the humpback whale population in Colombia was affected by collisions, and at least $5 \%$ of these collisions happened in Bahía Málaga (Capella et al., 2001; 2007). In addition, between 2013 and 2020 we recorded five humpback whales in the Málaga NNP area with injuries and scars associated with boat collisions. All boats used in Málaga NNP for whale watching are motorized and produce underwater noise. Several studies demonstrated that whales appeared capable to detect and recognize boat sounds at distances of up to 8-10 km (e.g. Corkeron, 1995). Noise pollution cause auditory damage, behavioral responses and stress, and disturb and mask their communication (Southall, 2005; Southall et al., 2008; Dunlop et al., 2010; Gomez et al., 2016). Boat presence generates behavioral changes (e.g. Watkins, 1986; Corkeron, 1995; Scheidat et al., 2004; Avila et al., 2015; Zapetis et al., 2017). The number and speed of boats, as well as directional changes were correlated with changes in behavior including respiration rates, diving intervals, swimming speed and aerial behavior, and such changes were elicited when boats were $0.5-1.0 \mathrm{~km}$ away (Bauer and Herman, 1986; Bauer et al., 1993). In the Northwest Atlantic, humpback whales co-occur with boat traffic and anthropogenic noise (Stimpert et al., 2011), as well as in the Gulf of Panama (Guzman et al., 2012) and in Málaga NNP in Colombia (Avila et al., 2017). In order to mitigate the risk of collisions and related noise pollution threats, we support Colombian recommendations to reduce vessel speed to 10 knots in the area during whale season, and when in the vicinity of whales to five knots or less and switching the engine to neutral when whales are close. Propeller guards for boats that transit in the area of whales are especially recommended, and it should be mandatory for large boats $(>80 \mathrm{~m})$, since most collisions are with this type of boat (Laist et al., 2001). Large boats as tourist cruise ships (with more than a thousand passengers and $>150$ m length) for example, represent a high risk of collisions with whales and high noise pollution (Carić, 2016). In this sense, it is important to note that current tourism in Málaga NNP is using small and medium boats ( 7 to $60 \mathrm{~m}$ length), so we suggest that this prevalence should be maintained, to reduce risk to whales and to maximize economic benefits for local communities. We also recommend promoting alternative land-based whale watching, which eliminates negative effects of boats on humpback whales. However, it is important to consider that this modality might not be as profitable as whale watching from boats. The land-based platform used in this study is located between the towns of Juanchaco and Ladrilleros at $20 \mathrm{msnm}$ (Figs 1 and 2E). This platform provides a magnificent view of humpback whales, especially using binoculars, and visitors could stay the whole 
day enjoining their presence, without causing any impact to the whales. Also, as humpback whales display sounds and songs in the area (Avila, 2000), we recommend the implementation of acoustic whale tourism. With the use of a hydrophone, this activity can be done at distances greater than $200 \mathrm{~m}$ from the whales, mitigating negative impacts from boats.

In addition, environmental education should be continued and reinforced, as the use of education in tourism activities could promote an environmentally sensitive attitude in tourists (Orams, 1995). In such tourist locations like Málaga NNP, permanent and continuous training efforts of both operators and interpreters is fundamental to promote the conservation of whales and their environment. However, in Málaga NNP its scope must be assessed and adjusted if necessary, so that the objective of enforcing best practices for whale watching is met. Environmental education should generate the necessary awareness so that in cases where the area is closed to tourism and there is no control and surveillance by environmental authorities, for example as happened in 2020 season, people follow the rules and recommendations. Besides, it is a major concern that boats coming from Buenaventura to run whalewatching trips are not arriving to Juanchaco dock for specific instructions and the company of a local interpreter. Therefore, we recommend authorities strengthen control and surveillance. In addition, it is necessary to formalize and qualify this training process in a technical, professional way by educational and training entities such as universities and the National Learning Service of Colombia- SENA. In addition, it is important to move towards greater articulation with local schools since they have an ecotourism profile, providing the possibility for students to carry out their internships in whale-watching monitoring. Whalewatching activities coupled with education experiences increase environmental awareness and when such experiences are led by adequate interpreters, they can serve as a source of inspiration and education, and raise conservation awareness (Orams, 1995; García-Cegarra and Pacheco, 2017).

Moreover, it is important to support and promote long-term studies, which will contribute to whale scientific research and to generate key information for decision-making for the management of the area. Formulation of priority lines of research and alliances with universities and institutions within the framework of the strategy for the conservation of the humpback whale of the Southeast Pacific (Flórez-González et al., 2007) and National Action Plan for the Conservation of Aquatic Mammals of Colombia should be identified (Trujillo et al., 2014).

Finally, based on these social, economic and biological aspects, we urge environmental authorities, conferring with relevant stakeholders, to determine the whale-watching carrying capacity of the area, which includes the number of boats per day in the area, as well as number of operators, guides and tourists on board. As in Málaga NNP many activities use boats, like fishing, whale-watching and transport, carrying capacity should include all types of boats. An assessment of whale-watching carrying capacity requires an understanding of the biological, social and economic dimensions (Fernandes and Rossi-Santos, 2018). Meanwhile, we suggest following the recommendations (MADS, 2017) as a precautionary measure, until more data and management capacity become available. Surveillance and reinforcement must be strengthened to ensure compliance with best practice recommendations. Ideally instead of whale-watching recommendations in the area, an enforceable legal instrument should be designed to ensure the ecological, social and economic sustainability of the activity. Progress in the social, economic and biological aspects should result in the maintenance of the conditions for the whales' welfare to maintain their breeding, birthing and rearing processes, the well-being of the communities, and an improvement of the tourist experience.

\section{Acknowledgments}

We thank staff members, researchers and volunteers (Volunteer Ranger Program) of Uramba Bahía Málaga National Park for collaboration in data collection, especially Héctor Montaño and Santiago Duarte. We acknowledge Fundación Yubarta for some data collection training, and local people of all Bahía Málaga communities (Juanchaco, Ladrilleros, La Barra, La Plata-Bahía Málaga, Chucheros-El Tigre and Puerto España-Miramar) for information and collaboration in the area. We give thanks to Julio Pérez (Bicivan) and Carolina García for photos. We thank Aldo Pacheco, Jaime Bolaños, Miriam Marmontel, an anonymous reviewer and specially Carolina García for valuable comments to improve the manuscript. ICA was supported by the Universidad del Valle and the Colombian Ministry of Science, Technology and Innovation (Call No 848 of 2019).

\section{References}

Amrein, A.M., Guzman, H.M., Surrey, K.C., Polidoro, B. and Gerber, L.R. (2020) Impacts of whale watching on the behavior of humpback whales (Megaptera novaeangliae) in the Coast of Panama. Frontiers in Marine Science 7: 601277.

https://doi.org/ 10.3389/fmars.2020.601277

Arias-Gaviria, D., Muñoz-Vargas, C.A. and Avila, I.C. (2011) Tourist Guide of Whalewatching in Colombia. Ministerio de Industria, Comercio y Turismo, Viceministerio de Turismo, Dirección de Calidad y Desarrollo Sostenible del Turismo, Bogotá, Colombia. 63 pp.

Avila, I.C. (2000) Algunos aspectos en el comportamiento superficial de la ballena jorobada (Megaptera novaeangliae) en los diferentes grupos conformados alrededor del par madrecría en el Pacífico colombiano. BSc. Thesis. Universidad del Valle. Cali, Colombia. 83 pp.

Avila, I.C. (2006) Patrones en la conducta superficial diurna de la ballena jorobada (Megaptera novaeangliae) en la Bahía de Málaga y zonas aledañas, Pacífico colombiano. M.Sc. Thesis. Universidad del Valle. Cali, Colombia. 90 pp.

Avila, I.C., Correa, L.M. and Parsons, E.C.M. (2015) Whalewatching activity in Bahía Málaga, on the Pacific coast of Colombia, and its effect on humpback whale (Megaptera novaeangliae) behavior. Tourism in Marine Environments 11(1): 19-32. https://doi.org/10.3727/154427315X14398263718394

Avila, I.C., Correa, L.M. and Van Waerebeek, K. (2017) Where humpback whales and vessel traffic coincide, a Colombian Pacific case study. Boletín del Museo Nacional de Historia Natural, Chile 66(1): 85-99.

Avila, I.C., Kaschner, K. and Dormann, C.F. (2018) Current global risks to marine mammals: taking stock of the threats. Biological Conservation 221(1): 44-58.

https://doi.org/10.1016/j.biocon.2018.02.021

Avila, I.C., Dormann, C.F., García, C., Payán, L.F. and Zorrilla, 
M.X. (2020) Humpback whales extend their stay in a breeding ground in the Tropical Eastern Pacific. ICES Journal of Marine Science 77: 109-118. https://doi.org/10.1093/icesjms/fsz251

Bauer, G.B. and Herman, L.M. (1986) The effect of boat traffic on the behavior of humpback whales in Hawaii. National Marine Fisheries Service, Report Contract No. 41 USC 252, Honolulu, USA. https://asa.scitation.org/doi/10.1121/1.407708

Bauer, G.B., Mobley, J.R. and Herman, L.M. (1993) Responses of wintering humpback whales to boat traffic. Journal of the Acoustical Society of America 94(3): 1848. [abstract]

https://doi.org/10.1121/1.407708

Capella, J., Flórez-González, L. and Falk, P. (2001) Mortality and anthropogenic harassment of humpback whales along the Pacific coast of Colombia. Memoirs of the Queensland Museum 47(2): 547-553.

Capella, J., Flórez-González, L., Herrera, J., Falk, P. and Tobón, I.C. (2007) Mortalidad y lesiones no letales de grandes cetáceos en Colombia ocasionadas por colisiones con embarcaciones. Pages 83-93 in Félix, F. (ed.) Memorias del taller de trabajo sobre el impacto de las actividades antropogénicas en mamíferos marinos en el Pacífico sudeste. Comisión Permanente del Pacífico Sur/Programa de las Naciones Unidas para el Medio Ambiente -CPPS/PNUMA, Guayaquil, Ecuador.

Available at http://cpps.dyndns.info/cpps-docsweb/planaccion/mamiferos/informes/MemoriasTaller-Mamiferos-Marinos-2006.pdf\#page=84

Carić, H. (2016). Challenges and prospects of valuation - cruise ship pollution case. Journal of Cleaner Production 111: 487-498. https://doi.org/10.1016/j.jclepro.2015.01.033

Castellanos-Galindo, G., Cantera, J.R., Espinosa, S. and Mejía Ladino, L.M. (2011) Use of local ecological knowledge, scientist's observations and grey literature to assess marine species at risk in a tropical eastern Pacific estuary. Aquatic Conservation: Marine and Freshwater Ecosystems 21: 37-48. https://doi.org/10.1002/aqc. 1163

Corkeron, P.J. (1995) Humpback whales (Megaptera novaeangliae) in Hervey Bay, Queensland: behaviour and responses to whale watching boats. Canadian Journal of Zoology 73(7): 1290-1299. https://doi.org/10.1139/z95-153

DW - DOLLAR WEB (2020) Dólar promedio año 2019.

Available online at $<$ https://dolar.wilkinsonpc.com.co/ divisas/dolar.html>. Consulted on 21 August 2020.

Dunlop, R.A., Cato, D.H. and Noad, M.J. (2010) Your attention please: increasing ambient noise levels elicits a change in communication behaviour in humpback whales (Megaptera novaeangliae). Proceedings of the Royal Society B: Biological Sciences 277(1693): 2521-2529.

https://doi.org/10.1098/rspb.2009.2319

Escobar, N. (2017) Gold is not always gold: Bahía Málaga, touristification strategies in the Colombian Pacific. Investigación y Desarrollo 25(2): 34-60.

http://clustercien.udea.edu.co/Papers/26854666002.pdf

Faria, M.A., DeWeerdt, J., Pace, F. and Mayer, F.X. (2013) Observation of a humpback whale (Megaptera novaeangliae) birth in the coastal waters of Sainte Marie Island, Madagascar. Aquatic Mammals 39: 296-305.

https://doi.org/10.1578/AM.39.3.2013.296

Fernandes, L. and Rossi-Santos, M.R. (2018) An integrated framework to assess the carrying capacity of humpback whale-watching tourism in Praia do Forte, Northeastern Brazil.
Pages 41-73 in Rossi-Santos M. and Finkl C. (eds) Advances in Marine Vertebrate Research in Latin America. Coastal Research Library, vol 22. Springer, Cham.

https://doi.org/10.1007/978-3-319-56985-7_3

Ferreira, M.E.C., Maia-Nogueira, R. and Hubner de Jesus, A. (2011) Surface observation of a birth of a humpback whale (Megaptera novaeangliae) on the northeast coast of Brazil. Latin American Journal of Aquatic Mammals 9(2): 160-163. https://doi.org/10.5597/lajam00182

Fiori, L., Martinez, E., Orams, M.B. and Bollard, B. (2019) Effects of whale-based tourism in Vava'u, Kingdom of Tonga: Behavioural responses of humpback whales to vessel and swimming tourism activities. PLOS ONE 14(7): e0219364.

https://doi.org/10.1371/journal.pone.0219364

Flórez-González, L., Avila, I.C., Capella, J., Falk, P., Félix, F., Gibbons, J., Guzmán, H., Haase, B., Herrera, J., Peña, V., Santillán, L., Tobón, I.C. and Van Waerebeek, K. (2007) The Conservation Strategy of the Southeastern Pacific humpback whale (Megaptera novaeangliae). Fundación Yubarta (ed.), Cali, Colombia. 106 pp.

García-Cegarra, A.M. and Pacheco, A.S. (2017) Whale-watching trips in Peru lead to increases in tourist knowledge, proconservation intentions and tourist concern for the impacts of whale-watching on humpback whales. Aquatic Conservation: Marine and Freshwater Ecosystems 27(5): 1011-1020.

https://doi.org/10.1002/aqc.2754

Gomez, C., Lawson, J.W., Wright, A.J., Buren, A.D., Tollit, D. and Lesage, V. (2016) A systematic review on the behavioural responses of wild marine mammals to noise: the disparity between science and policy. Canadian Journal of Zoology 94(12): 801-819.https://doi.org/10.1139/cjz-2016-0098

Guzman, H.M., Gomez, C.G., Guevara, C.A. and Kleivane, L. (2012) Potential vessel collisions with Southern Hemisphere humpback whales wintering off Pacific Panama. Marine Mammal Science 29(4): 629-642.

https://doi.org/10.1111/j.1748-7692.2012.00605.x

Hoyt, E. and Iñíguez, M. (2008) Estado del Avistamiento de Cetáceos en América Latina. WDCS, Chippenham, UK. 59 pp.

Hoyt, E. and Parsons, E.C.M. (2014) The whale-watching industry: historical development. Pages 57-70 in Higham, J., Bjeder, L. and Wiliams, R. (eds) Whale-watching, sustainable tourism and ecological management. Cambridge University Press, Cambridge.

IWC- International Whaling Commission (2020) Whale Watching Handbook. Available online at < https://wwhandbook.iwc.int>. Consulted on 10 July 2020.

Laist, D.W., Knowlton, A.R., Mead, J.G., Collet, A.S. and Podesta, M. (2001) Collisions between ships and whales. Marine Mammal Science 17: 35-75.

https://doi.org/10.1111/j.1748-7692.2001.tb00980.x

Lusseau, D. and Bejder, L. (2007) The long-term consequences of short-term responses to disturbance: Experiences from whale-watching impact assessment. International Journal of Comparative Psychology 20(2): 228-236.

https://doi.org/10.5070/P4202009991

MADS - Ministerio de Ambiente y Desarrollo Sostenible (2017) Guía de avistamiento responsable de mamíferos acuáticos en Colombia. Ministerio de Ambiente y Desarrollo Sostenible, Bogotá, Colombia. 72 pp.

Morete, M.E., Bisi, T.L. and Rosso, S. (2007) Mother and calf humpback whale responses to vessels around the Abrolhos 
Archipelago, Bahia, Brazil. Journal of Cetacean Research and Management 9(3): 241-248.

O'Connor, S., Campbell, R., Cortez, H. and Knowles, T. (2009) Whale watching worldwide: Tourism numbers, expenditures and expanding economic benefits. Yarmouth, MA: International Fund for Animal Welfare. 295 pp.

Oña, J., Duque, E., Garland, E.C., Seger, K., Narváez, M., Maldonado, J. and Denkinger, J. (2019) A giant's dance: underwater social and vocal behavior of humpback whales (Megaptera novaeangliae) recorded on the Northern Coast of Ecuador. Aquatic Mammals 45(4): 456-464. https://doi.org/10.1578/AM.45.4.2019.456

Orams, M.B. (1995) Towards a more desirable form of ecotourism. Tourism management 16: 3-8.

Parsons, E.C.M. (2012) The negative impacts of whale-watching. Journal of Marine Biology 2012: 1-9.

https://doi.org/10.1155/2012/807294

Pauly, D. and Zeller, D. (2015) Catch reconstructions reveal that global marine fisheries catches are higher than reported and declining. Nature Communications 7: 1-9.

https://doi.org/10.1038/ncomms10244

Payne, R.S. and McVay, S. (1971) Songs of humpback whales. Science 173(3997): 585-597.

https:doi.org/10.1126/science.173.3997.585

Rangel, J.O. (2004) La vegetación del Chocó biogeográfico de Colombia. Pages 769-815 in Rangel, J.O. (ed.) Diversidad Biótica IV. El chocó Biogeográfico/Costa Pacífica. Universidad Nacional de Colombia, Instituto de Ciencias Naturales, Conservación Internacional, Bogotá, Colombia.

Scheidat, M., Castro, C., González, J. and Williams, R. (2004) Behavioural responses of humpback whales (Megaptera novaeangliae) to whalewatching boats near Isla de la Plata, Machalilla National Park, Ecuador. Journal of Cetacean Research and Management 6: 63-68.

Schoeman, R.P., Patterson-Abrolat, C. and Plön, S. (2020) A global review of vessel collisions with marine animals. Frontiers in Marine Science 7: 292.

https://doi.org/10.3389/fmars.2020.00292

Soto-Cortés, L.V., Luna-Acosta, A. and Maya, D.L. (2021) Whalewatching management: assessment of sustainable governance in Uramba Bahía Málaga National Natural Park, Valle del Cauca. Frontiers in Marine Science 8: 575866

https://doi.org/10.3389/fmars.2021.575866

Southall, B.L. (2005) Shipping noise and marine mammals: A forum for science, management, and technology. Final report of the National and Atmospheric Administration (NOAA) International
Symposium. [Available at_<http://www.beamreach.org/wiki/ images/4/47/2004NoiseReport.pdf>].

Southall, B.L., Bowles, A.E., Ellison, W.T., Finneran, J.J., Gentry, R.L., Greene Jr, C.R., Kastak, D., Ketten, D.R., Miller, J.H., Nachtigall, P.E. and Richardson, W.J. (2008) Marine mammal noise-exposure criteria: initial scientific recommendations. Bioacoustics 17: 273-275.

https://doi.org/10.1080/09524622.2008.9753846

Stimpert, A.K., Au, W.W., Parks, S.E., Hurst, T. and Wiley, D.N. (2011) Common humpback whale (Megaptera novaeangliae) sound types for passive acoustic monitoring. Journal of the Acoustical Society of America 129: 476-482.

https://doi.org/10.1121/1.3504708

Trujillo, F., Caicedo, D. and Diazgranados, M.C. (eds) (2014) Plan de acción nacional para la conservación de los mamíferos acuáticos de Colombia (PAN mamíferos Colombia). Ministerio de Ambiente y Desarrollo Sostenible, Fundación Omacha, Conservación Internacional y WWF. Bogotá, 54 p.

Van Waerebeek, K., Baker, A.N., Félix, F., Gedamke, J., Iñiguez, M., Sanino, G.P., Secchi, E.R., Sutaria, D., Helden, A.V. and Wang, Y. (2007) Vessel collisions with small cetaceans worldwide and with large whales in the Southern Hemisphere, an initial assessment. Latin American Journal of Aquatic Mammals 6: 43-69.

https://doi.org/10.5597/lajam00109

Watkins, W.A. (1986) Whale reactions to human activities in Cape Cod waters. Marine Mammal Science 2(4): 251-262.

https://doi.org/10.1111/j.1748-7692.1986.tb00134.x

Weilgart, L.S. (2007) A brief review of known effects of noise on marine mammals. International Journal of Comparative Psychology 20(2): 159-168.

https://doi.org/10.5070/P4202009986

Wright, A.J., Soto, N.A., Baldwin, A.L., Bateson, M., Beale, C.M., Clark, C., Deak, T., Edwards, E.F., Fernández, A., Godinho, A. and Hatch, L.T. (2007) Do marine mammals experience stress related to anthropogenic noise? International Journal of Comparative Psychology 20(2): 274-316.

https://doi.org/10.5070/P4202009994

Zapetis, M.E., Samuelson, M.M., Botero, N. and Kuczaj, S.A. (2017) Evaluation of a developing ecotourism industry: Whale watching in the Gulf of Tribugá, Colombia. International Journal of Comparative Psychology 30(1): 1-16.

https://doi.org/10.5070/P4301032072

Zeppel, H. and Muloin, S. (2008) Conservation benefits of interpretation on marine wildlife tours. Human Dimensions of Wildlife 13(4): 280-294.

https://doi.org/10.1080/10871200802187105 